\title{
Human Dimensions of Wildlife
}

An International Journal

\section{Once I found out: Awareness of and attitudes toward coyote hunting policies in Massachusetts}

\author{
Jennifer L. Jackman \& Jonathan G. Way
}

To cite this article: Jennifer L. Jackman \& Jonathan G. Way (2017): Once I found out: Awareness of and attitudes toward coyote hunting policies in Massachusetts, Human Dimensions of Wildlife, DOI: 10.1080/10871209.2017.1397824

To link to this article: http://dx.doi.org/10.1080/10871209.2017.1397824

$$
\text { 曲 Published online: } 14 \text { Nov } 2017 .
$$

Submit your article to this journal $₫$

Q View related articles $\square$

View Crossmark data $\asymp$ 


\title{
Once I found out: Awareness of and attitudes toward coyote hunting policies in Massachusetts
}

\author{
Jennifer L. Jackman ${ }^{\mathrm{a}}$ and Jonathan G. Way ${ }^{\mathrm{b}}$ \\ ${ }^{a}$ Department of Political Science, Salem State University, Salem, Massachusetts, USA; ${ }^{b}$ Eastern Coyote/Coywolf \\ Research, Osterville, Massachusetts, USA
}

\begin{abstract}
Lethal management of large carnivores such as wolves, cougars, bear, bobcat, and coyotes has been found to have negative ecological, behavioral, and socio-political consequences, and has contributed to humanwildlife conflict. Recent research has documented an increase in the popularity of large predators and decrease in support for their lethal removal, particularly when methods are perceived as inhumane or unfair. Our survey results indicated that voters on Cape Cod, Massachusetts overwhelmingly opposed coyote hunting practices such as baiting and supported changing these policies. We suggest that either (1) state wildlife agencies broaden their constituents to include the general public (i.e. not just hunters) in their decision-making; (2) citizens initiate more ballot initiatives to better protect carnivores; and/or (3) policymakers reform carnivore management in line with the compassionate conservation paradigm, which would likely have broad public support given our findings.
\end{abstract}

\section{KEYWORDS}

Coyotes; carnivore management; bag limits; baiting; ballot initiative

\section{Introduction}

Increasingly, questions have been raised about the acceptability, desirability, and ethics of lethal removal of large carnivores such as wolves, cougars, bear, bobcat, and coyotes (Bruskotter, Vaske, \& Schmidt, 2009; Treves et al., 2015; Treves, Naughton-Treves, \& Shelley, 2013). A growing body of evidence points to the negative ecological and behavioral consequences of hunting carnivores, which, in turn, can exacerbate human-wildlife conflicts and affect attitudes toward wildlife (Estes et al., 2011; Gilbert et al., 2016; Ripple et al., 2014; Robinson, Wielgus, Cooley, \& Cooley, 2008). Hunting pressure on large carnivores can have disruptive effects on social structure, movement patterns, and behavior. These impacts can undermine their ecological role as apex predators, increase immigration, and result in a younger overall age structure (Brook, Johnson, \& Ritchie, 2012; Cooley, Wielgus, Robinson, Koehler, \& Maletzke, 2009; Gilbert et al., 2016; Ordiz, Bischof, \& Swenson, 2013; Ordiz, Støen, et al., 2013; Ripple et al., 2014; Robinson et al., 2008). Population turnover as a result of lethal removal may worsen the very conflicts that wildlife managers seek to reduce as younger, more inexperienced animals replace older ones (Maletzke et al., 2014; Way, 2007; Way, Timm, \& Strauss, 2009). Professional wildlife organizations (e.g. American Society of Mammalogists) and leading researchers have come out against lethal removal of predators and have urged wildlife agencies to focus on nonlethal control (Bergstrom, 2017; Treves, Krofel, \& McManus, 2016). 
Human dimensions research documents the erosion of public support for lethal management of large carnivores (Jackman \& Rutberg, 2015; Teel \& Manfredo, 2010). Public opposition to hunting a particular species and specific hunting practices (e.g. baiting, trapping) has stimulated state ballot initiatives (Manfredo, Fulton, \& Pierce, 1997; Minnis, 1998). At the same time, large predators have gained in popularity (George, Slagle, Wilson, Moeller, \& Bruskotter, 2016).

Lethal control has resulted in devaluation of large carnivores, decreased tolerance, undermined positive attitudes toward wildlife, and generated public opposition to wildlife managers (Bruskotter et al., 2009; Hogberg, Treves, Shaw, \& Naughton-Treves, 2015; Treves \& Bruskotter, 2014; Treves et al., 2015, 2013). Non-lethal methods of wildlife management are perceived as more humane than lethal methods (Slagle, Bruskotter, Singh, \& Schmidt, 2017) and more effective in reducing conflicts (Bergstrom, 2017). State agencies, however, routinely dismiss public views, ignore the ecological importance of carnivores, and allow the killing of carnivores with no scientifically sound justification (Kane \& Way, 2014; Ripple et al., 2014).

Voters in Massachusetts, for example, in 1996, approved a ballot measure, the Wildlife Protection Act (WPA), which banned body-gripping traps and prohibited the use of dogs or bait in hunting black bears and bobcats (Deblinger, Woytek, \& Zwick, 1999). Subsequently, voter surveys in 2005 and 2012 found increasing acceptance, decreasing fear, and increasing opposition to lethal management of coyotes (Jackman \& Rutberg, 2015). Despite public opposition to lethal wildlife management, the state wildlife board over the past decade enacted a series of regulatory changes expanding the hunting of coyote (Massachusetts Fisheries and Wildlife Board, 2008), bobcat (Massachusetts Division of Fisheries and Wildlife, 2008), and bear (Haddadin, 2015) in response to hunter requests. Legislation has been proposed to remove WPA restrictions on trapping, hounding, and baiting (MSPCA, 2015).

While Massachusetts is one of the only states that does not have a year-round season on coyotes, coyotes still can be baited with and shot over food, called in with electronic predator calls, hounded with dogs, hunted at night, and killed with no restrictions on size, age, sex, or number between October and March (Kane \& Way, 2014). In 2013-2014, 420 coyotes were killed statewide during the hunting season (Massachusetts Division of Fisheries and Wildlife, 2014). Yet, while increasing the hunting season for coyotes, the state wildlife agency has used the absence of predators as justification for expansion of white-tailed deer hunting to control deer populations. The expansion of coyote hunting has ignored the agency's own estimate that coyotes account for $20-40 \%$ of fawn mortality (Massachusetts Department of Conservation and Recreation \& Division of Fisheries and Wildlife, 2015) and other evidence that coyotes are effective in killing deer and reducing regional deer abundance (Benson, Loveless, Rutledge, \& Patterson, 2017; Kilgo, Ray, Ruth, \& Miller, 2010).

Our survey of Cape Cod voters examined knowledge of and attitudes toward current coyote hunting policies and practices in Massachusetts. We anticipated that the voters would oppose coyote hunting practices that are perceived as unfair or inhumane (e.g. baiting). We also examined voter's willingness to take action (i.e. vote) to end policies that they oppose.

\section{Methods}

Our survey was conducted in the summer of 2012 (see Jackman \& Rutberg, 2015, for details). Using Dillman, Smythe and Christian's (2014) multiple contact method, the survey was mailed to a random sample of 1,800 registered voters in Barnstable County, 
Massachusetts (i.e. Cape Cod). Voter lists were stratified by three regions of Cape Cod (Upper Cape, Mid Cape, and Lower Cape).

Respondents were asked if they were aware that "Massachusetts has a coyote hunting season" (true/false), "there are no limits on how many coyotes a hunter can kill during hunting season" (yes/no), and "it is legal to bait coyotes with food to shoot them" (yes/no). Responses of "false" and "no" were coded as unaware (0); "true" and "yes" responses were coded as aware (1). Respondents indicated their level of support for "allowing hunters to kill unlimited numbers of coyotes" and "allowing hunters to bait coyotes" following respective awareness questions. Respondents also were asked their views about the WPA: "In 1996, Massachusetts voters passed the Wildlife Protection Act, a law restricting the use of bodygripping traps for coyotes and other fur-bearing mammals. To what extent do you support the current law restricting the trapping of coyotes?" Attitudes toward these policies were measured on a five-point scale, from strongly oppose (-2) to strongly support (2). The survey also asked respondents if they would support a hypothetical ballot initiative "to make it unlawful to hunt coyotes with bait." Responses ranged on a five-point scale from "very unlikely to vote in favor of a ban on coyote baiting" $(-2)$ to "very likely to vote in favor of a ban on coyote baiting" (2). Respondents indicated how often they participate in "going hunting" on a five-point scale from never (1) to very often (5). To facilitate analysis, the hunting participation variable was recoded into never (1), rarely (2-3) and frequently (4-5).

Chi-square tests were used to assess relationships between categorical variables. Cramer's $V$ was the effect size measure: .1 was interpreted as minimal, .3 as typical, and .5 or more as substantial (Vaske, 2008). Independent sample $t$-tests compared mean responses of awareness and sex sub-groups with Cohen's $d$ as effect size (i.e. minimal relationship $=.20$, typical relationship $=.50$, substantial relationship $=.80)$ (Vaske, 2008). One-way analysis of variance (ANOVA) with Tahame post-hoc tests compared hunter participation group mean responses using effect size measures (i.e. $\eta$ ) with .10 as a minimal relationship, .243 as a typical relationship, and .371 as a substantial relationship (Vaske, 2008). Significance was set at $p<.05$.

\section{Results}

A total of 715 voters completed the survey (with 151 surveys undeliverable) for a response rate of $43 \%$. After non-response bias checks, the sample was weighted for sex, region, and age using voter population data. Of respondents, $90 \%$ never hunted $(n=633), 5 \%$ rarely hunted $(n=32)$, and $6 \%$ frequently hunted $(n=39)$. Hunters were predominantly male; $79 \%$ of frequent hunters and $81 \%$ of those who rarely hunt were male $\left(\chi^{2}=35.70, p<.001, V=.225\right)$. Hunting participation in the three Cape Cod regions did not differ $\left(\chi^{2}=3.71, p=.156, V=.075\right)$.

\section{Awareness of coyote hunting policies and practices}

Cape Cod voters were largely unaware of coyote hunting policies (Table 1). Only $40 \%$ of respondents knew that Massachusetts has a coyote hunting season. Fourteen percentage were aware that there are no limits on the number of coyotes a hunter can kill within a season (i.e. no bag limits), and just 10\% were aware that bait can be used to hunt coyotes. Frequent hunters had higher levels of awareness of the coyote hunting season than those who never or rarely hunted $\left(\chi^{2}=32.32, p<.001, V=.221\right)$, absence of bag limits on coyotes $\left(\chi^{2}=71.62, p<.001, V=.389\right)$ and use of bait to hunt coyotes $\left(\chi^{2}=61.90, p<.001, V=.395\right)$. Men were more aware than 
Table 1. Awareness of Massachusetts coyote hunting policies.

\begin{tabular}{|c|c|c|c|}
\hline & Aware coyote hunting season ${ }^{\mathrm{a}} \%$ & Aware no bag limits ${ }^{\mathrm{b}} \%$ & Aware baiting is allowed ${ }^{\mathrm{b}} \%$ \\
\hline Total & 40 & 14 & 10 \\
\hline \multicolumn{4}{|c|}{ Hunting Participation } \\
\hline Never & 37 & 10 & 7 \\
\hline Rarely & 44 & 31 & 13 \\
\hline Frequently & 84 & 67 & 58 \\
\hline \multicolumn{4}{|l|}{ Sex } \\
\hline Female & 35 & 8 & 4 \\
\hline Male & 46 & 22 & 16 \\
\hline \multicolumn{4}{|l|}{ Region } \\
\hline Mid Cape & 39 & 16 & 10 \\
\hline Upper Cape & 37 & 11 & 7 \\
\hline Lower Cape & 46 & 17 & 13 \\
\hline
\end{tabular}

${ }^{a}$ Variable coded as True/False. Reported percentages = True.

${ }^{\mathrm{b}}$ Variables coded as Yes/No. Reported percentages $=$ Yes.

women of the coyote hunting seasons $\left(\chi^{2}=7.20, p=.007, V=.105\right)$, lack of bag limits on coyotes $\left(\chi^{2}=28.41, p<.001, V=.200\right)$, and legality of baiting $\left(\chi^{2}=27.64, p<.001, V=.196\right)$. Awareness of the coyote hunting season $\left(\chi^{2}=3.69, p=.158, V=.075\right)$, lack of bag limits $\left(\chi^{2}=5.95, p=.051\right.$, $V=.091)$, and legality of baiting $\left(\chi^{2}=4.98, p=.083, V=.085\right)$ did not vary by region.

\section{Attitudes toward hunting policies and practices}

When respondents were informed later in the survey that in Massachusetts hunters can kill unlimited numbers of coyotes during the hunting season and that it is legal to shoot coyotes over bait, few supported these policies. Only 23\% supported no-bag limits, compared with $57 \%$ who opposed the policy (Table 2). In other words, 2.5 times more respondents opposed allowing hunters to kill unlimited number of coyotes than supported the policy. Frequent hunters were the only group to indicate majority support (62\%) of the no-bag limit policy (Tables 2 and 3). Mid Cape $(M=-.56)$, Upper Cape $(M=-.52)$ and Lower Cape $(M=-.60)$ voters opposed the policy $(F=.211, p=.809, \eta=.025)$. Women $(M=-.79)$ were more likely than men $(M=-.28)$ to oppose the lack of bag limits $(t=4.866, p<.001, d=-.39)$.

Opposition to coyote baiting was even stronger, with $65 \%$ opposed and $16 \%$ in support (Table 2). In total, 4.1 times more respondents opposed baiting than supported the practice. Only frequent hunters showed majority support (58\%) for baiting (Tables 2 and 3). Voters in the Mid Cape $(M=-.89)$, Upper Cape $(M=-.77)$, and Lower Cape $(M=-.92)$ regions opposed coyote baiting $(F=.90, p=.405, \eta=.051)$. The majority of both male and female voters were against coyote baiting (Table 2$)$, with women $(M=-1.07)$ more opposed than men $(M=-.59)(t=5.137$, $p<.001, d=-.39)$.

\section{Support for wildlife protection measures}

Sixty-two percentage of respondents favored a hypothetical ballot measure to ban coyote baiting. Only $22 \%$ were unlikely to vote for the initiative (Table 2). Thus, 2.8 times more people favored a hypothetical ban on coyote baiting compared with opposing the ban. Only frequent hunters opposed it (Tables 2 and 3). Respondents in the Mid Cape $(M=.75)$, Upper Cape $(M=.65)$, and Lower Cape $(M=.77)$ supported the ban $F=.496 . p=.609, \eta=.038)$. The majority of both 
Table 2. Attitudes toward coyote hunting policies.

\begin{tabular}{|c|c|c|c|c|c|c|c|c|}
\hline & \multicolumn{2}{|c|}{ No Bag Limits ${ }^{a}$} & \multicolumn{2}{|c|}{ Baiting $^{a}$} & \multicolumn{2}{|c|}{ Baiting Ban $^{\mathrm{b}}$} & \multicolumn{2}{|c|}{$W A^{a}$} \\
\hline & Support \% & Oppose \% & Support \% & Oppose \% & Support \% & Oppose \% & Support \% & Oppose \% \\
\hline Total & 23 & 57 & 16 & 65 & 62 & 22 & 68 & 14 \\
\hline \multicolumn{9}{|l|}{ Hunting Participation } \\
\hline Never & 23 & 59 & 13 & 68 & 65 & 20 & 70 & 11 \\
\hline Rarely & 21 & 64 & 22 & 63 & 58 & 21 & 84 & 9 \\
\hline Frequently & 62 & 15 & 58 & 24 & 18 & 66 & 29 & 55 \\
\hline \multicolumn{9}{|l|}{ Sex } \\
\hline Female & 16 & 64 & 10 & 73 & 66 & 17 & 72 & 10 \\
\hline Male & 31 & 48 & 22 & 56 & 57 & 29 & 64 & 19 \\
\hline \multicolumn{9}{|l|}{ Region } \\
\hline Mid Cape & 22 & 55 & 13 & 64 & 60 & 21 & 67 & 16 \\
\hline Upper Cape & 22 & 58 & 18 & 65 & 59 & 23 & 66 & 14 \\
\hline Lower Cape & 24 & 57 & 15 & 67 & 68 & 22 & 73 & 11 \\
\hline
\end{tabular}

${ }^{\mathrm{a}}$ Reported percentages of support $=$ strongly support + somewhat support and oppose $=$ strongly oppose + somewhat oppose.

${ }^{\mathrm{b}}$ Reported percentages of support $=$ very likely and somewhat likely to vote in favor and oppose $=$ very unlikely + somewhat unlikely to vote in favor.

Table 3. Attitudes toward coyote hunting policies by hunting participation.

\begin{tabular}{lcccccc}
\hline & \multicolumn{3}{c}{ Hunting participation } & & \\
Attitude & Never (M) & Rarely (M) & Frequently (M) & $F$ & $p$ & $\eta$ \\
\hline No bag limits ${ }^{\mathrm{a}, \mathrm{c}}$ & $-.65^{\mathrm{A}}$ & $-.79^{\mathrm{A}}$ & $.99^{\mathrm{B}}$ & 29.602 & $<.001$ & .282 \\
Baiting $^{\mathrm{a}, \mathrm{c}}$ & $-.95^{\mathrm{A}}$ & $-.77^{\mathrm{A}}$ & $.75^{\mathrm{B}}$ & 36.857 & $<.001$ & .311 \\
Baiiting Ban $^{\mathrm{b}, \mathrm{c}}$ & $.81^{\mathrm{A}}$ & $.68^{\mathrm{A}}$ & $-.91^{\mathrm{B}}$ & 27.802 & $<.001$ & .271 \\
Wildlife Protection Act $^{\mathrm{a}, \mathrm{c}}$ & $1.10^{\mathrm{A}}$ & $1.07^{\mathrm{A}}$ & $-.55^{\mathrm{B}}$ & 34.976 & $<.001$ & .306 \\
\hline
\end{tabular}

${ }^{a}$ Means derived from a 5 -point scale where $-2=$ strongly oppose, $0=$ neutral, and $2=$ strongly support.

${ }^{\mathrm{b}}$ Means derived from a 5 -point scale where $-2=$ very unlikely to vote in favor, $0=$ neutral, and $2=$ very likely to vote in favor.

'Any 2 means that do not have the same superscript are significantly different at $p<.05$.

women and men favored the baiting ban (Table 2), although women $(M=.91)$ were more supportive than men $(M=.49)(t=3.643, p<.001, d=.29)$.

The willingness to vote for the coyote baiting ban closely paralleled continuing WPA support (Table 2.) Sixty-eight percentage of respondents supported the WPA, while $14 \%$ opposed it. In other words, 3.1 times as many voters supported the law than opposed it. Only frequent hunters opposed the WPA (Tables 2 and 3). Voters in the Mid Cape $(M=.94)$, Upper Cape $(M=.94)$, and Lower Cape $(M=1.13)$ regions supported the WPA $(F=1.59, p=.205, \eta=.068)$. Women $(M=1.16)$ were more supportive than men $(M=.79)(t=3.71, p<.001, d=.29)$.

\section{Discussion}

Lethal methods of wildlife management generally do not work and put wildlife managers on a collision course with shifting public attitudes (Bruskotter et al., 2009; Hogberg et al., 2015; Treves \& Bruskotter, 2014; Treves et al., 2013). Lethal removal of predators resolves neither human-wildlife conflict nor public conflict over wildlife management (Cooley et al., 2009; Robinson et al., 2008; Slagle et al., 2017). Conversely, pre-emptive actions on the part of 
wildlife managers to end practices that are perceived as unfair and cruel may enhance public acceptability of wildlife management (Bruskotter et al., 2009; Treves et al., 2015).

We found that voters on Cape Cod were largely unaware of current coyote hunting policies and practices in Massachusetts. When they learned in the survey that hunters could kill unlimited numbers of coyotes during the hunting season and use bait to hunt them legally in Massachusetts, they opposed these policies by wide margins, with the exception of frequent hunters, who comprise a very small segment of the sampled public. The high level of opposition to these policies indicates the potential for mobilization as these practices become more visible. Additionally, frequent hunters, who comprised $6 \%$ of our sample, were likely over-represented in our sample given USFWS (2011) statistics on hunting numbers in Massachusetts (i.e., .7\% of the population). Wildlife watchers are a much higher percentage of the population than hunters in the state. In Massachusetts, in 2011 alone, 1.8 million people spent \$1.3 billion on wildlife watching, which is 32.6 times more people and 14.6 times more money than the $\$ 87$ million spent on hunting (USFWS, 2011). These trends and our results highlight the importance of considering and involving broader constituencies in wildlife management decision-making.

Voters also supported wildlife protections, and indicated a willingness to use the ballot measure mechanism to stop hunting practices that they find objectionable such as coyote baiting. When the WPA was adopted in 1996, 61\% of Cape Cod voters voted for the measure (Massachusetts Secretary of State, 2017), and we found that this strong support has endured two decades later. While the hypothetical ballot measure to ban coyote baiting that we posed was in the absence of any pro or con campaigns, the belief that trapping was cruel and inhumane has contributed to the adoption of state trapping bans (Manfredo et al., 1997; Minnis, 1998). Restoring the use of body gripping traps clearly goes against the voter viewpoints evidenced in this article and has no scientific foundation. The particularly strong opposition of female voters to baiting and unlimited coyote hunting reflects gender gaps that fuel animal protection ballot measure victories (Jackman, 2010) since women are registered and turnout to vote at a higher rate than men (Center for American Women and Politics, 2012).

\section{New wildlife management paradigm: Compassionate conservation}

The time has come for changing wildlife management policies and practices to incorporate ethics, values, and views of a significant proportion of the US public and to recognize the ecological and aesthetic importance of large carnivores (Vucetich \& Nelson, 2014). Compassionate conservation is an increasingly important wildlife management paradigm whereby the overarching goal is to first do no harm and to consider the intrinsic worth of individual animals in management practices (Ramp \& Bekoff, 2015; Wallach, Bekoff, Nelson, \& Ramp, 2015). Given our results, this approach to wildlife management would likely have strong support. Restricting hunting seasons and methods of killing goes hand and hand with compassionate conservation, even if common animals (e.g., coyotes) are not in danger of extinction. The proposed Carnivore Conservation Act of Massachusetts (Kane \& Way, 2014), for example, seeks a balance that could be used to reform carnivore management. The Act would shorten hunting seasons, institute bag limits, eliminate unpopular hunting practices such as baiting, and provide refuges from hunting (Ramp 
\& Bekoff, 2015; Wallach et al., 2015), yet permit limited hunting for the small minority of people that participate in that activity.

In conclusion, we suggest that (1) state wildlife agencies broaden their constituents to include the general public (i.e. not just hunters) in their decision-making (Peterson \& Nelson, 2017) and recognize the extensive body of scientific and human dimensions research that directly challenges lethal predator removal; (2) citizens initiate more ballot initiatives to better protect carnivores; and/or (3) state and federal policy makers adopt policies consistent with the compassionate conservation paradigm.

\section{Funding}

This work was supported by a Summer Research and Creative Activity Grant from Salem State University.

\section{References}

Benson, J. F., Loveless, K. M., Rutledge, L. Y., \& Patterson, B. R. (2017). Ungulate predation and ecological roles of wolves and coyotes in eastern North America. Ecological Applications, 27(3), 718-733. doi:10.1002/eap.2017.27.issue-3

Bergstrom, B. J. (2017). Carnivore conservation: Shifting the paradigm from control to coexistence. Journal of Mammalogy, 98, 1-6. doi:10.1093/jmammal/gyw185

Brook, L. A., Johnson, C. N., \& Ritchie, E. G. (2012). Effects of predator control on behaviour of an apex predator and indirect consequences for mesopredator suppression. Journal of Applied Ecology, 49(6), 1278-1286. doi:10.1111/j.1365-2664.2012.02207.x

Bruskotter, J., Vaske, J., \& Schmidt, R. H. (2009). Social and cognitive correlates of Utah residents' acceptance of the lethal control of wolves. Human Dimensions of Wildlife, 14, 119-132. doi:10.1080/10871200802712571

Center for American Women and Politics. (2012). Gender differences in voter turnout. Retrieved from www.cawp.rutgers.edu/fast_facts/voters/documents/genderdiff.pdf

Cooley, H. S., Wielgus, R. B., Robinson, H. S., Koehler, G. M., \& Maletzke, B. T. (2009). Does hunting regulate cougar populations? A test of the compensatory mortality hypothesis. Ecology, 90, 2913-2921. doi:10.1890/08-1805.1

Deblinger, R. D., Woytek, W. A., \& Zwick, R. R. (1999). Demographics of voting on the 1996 Massachusetts ballot referendum. Human Dimensions of Wildlife, 4(2), 40-55. doi:10.1080/ 10871209909359150

Dillman, D., Smyth, J. D., \& Christian, L. M. (2014). Internet, phone, mail, and mixed-mode surveys: The tailored design method. Hoboken, New Jersey: John Wiley \& Sons, Inc.

Estes, J. A., et al. 2011. Trophic downgrading of planet earth. Science, 333, 301-306.

George, K. A., Slagle, K. M., Wilson, R. S., Moeller, S. J., \& Bruskotter, J. T. (2016). Changes in attitudes toward animals in the United States from 1978 to 2014. Biological Conservation, 201, 237-242. doi:10.1016/j.biocon.2016.07.013

Gilbert, S. L., Sivy, K. J., Pozzanghera, C. B., DuBour, A., Overduijn, K., Smith, M. M., ... Prugh, L. R. (2016). Socioeconomic benefits of large carnivore recolonization through reduced wildlifevehicle collisions. Conservation Letters. doi:10.1111/conl.12280

Haddadin, J. (2015). Black bear hunting on track to expand in Massachusetts. Metrowest Daily News. Retrieved from http://www.metrowestdailynews.com/article/20150201/News/150209776

Hogberg, J., Treves, A., Shaw, B., \& Naughton-Treves, L. (2015). Changes in attitudes toward wolves before and after an inaugural public hunting and trapping season: Early evidence from Wisconsin's wolf range. Environmental Conservation, 43, 45-55. doi:10.1017/ S037689291500017X 
Jackman, J. (2010). Animal policy and the gender gap. In M. Bekoff (Ed.), Encyclopedia of animal rights and animal welfare, Volume 1 (pp. 287-291). Westport, CT: Greenwood Press.

Jackman, J., \& Rutberg, A. (2015). Shifts in attitudes toward Coyotes on the urbanized East Coast: The Cape Cod Experience, 2005-2012. Human Dimensions of Wildlife, 20(4), 333-348. doi:10.1080/10871209.2015.1027973

Kane, L., \& Way, J. G. (2014). Carnivore Conservation Act of Massachusetts. (Revised June 2014; original version July 2013). 21 pages. Retrieved from http://www.EasternCoyoteResearch.com/ downloads/MACarnivoreConservationActJune2014.pdf

Kilgo, J. C., Ray, H. S., Ruth, C., \& Miller, K. V. (2010). Can coyotes affect deer populations in Southeastern North America? Journal of Wildlife Management, 74(5), 929-933. doi:10.2193/2009-263

Maletzke, B. T., Wielgus, R., Koehler, G. M., Swanson, M., Cooley, H., \& Alldredge, J. R. (2014). Effects of hunting on cougar spatial organization. Ecology and Evolution, 4(11), 2178-2185.

Manfredo, M. J., Fulton, D. C., \& Pierce, C. L. (1997). Understanding voter behavior on wildlife ballot initiatives: Colorado's trapping amendment. Human Dimensions of Wildlife, 2(4), 22-39. doi:10.1080/10871209709359106

Massachusetts Department of Conservation and Recreation \& Division of Fisheries and Wildlife. (2015). Blue Hills State Reservation Deer Management Plan. Retrieved from http://www.mass.gov/ eea/docs/dcr/news/public-meetings/materials/parklands/blue-hills-deer-management-plan.pdf

Massachusetts Division of Fisheries and Wildlife. (2008). Annual Report. Retrieved from http:// www.mass.gov/eea/docs/dfg/dfw/publications/annual-reports/annual-report-fy08.pdf

Massachusetts Division of Fisheries and Wildlife. (2010). Annual Report. Retrieved from http:// www.mass.gov/eea/docs/dfg/dfw/publications/annual-reports/fy2010-dfw-annual-report.pdf

Massachusetts Division of Fisheries and Wildlife (2014). Annual Report. Retrieved from http://www. mass.gov/eea/agencies/dfg/dfw/publications/2014-dfw-anrep-final.pdf

Massachusetts Secretary of State. (2017). Massachusetts Election Statistics. Retrieved from http:// electionstats.state.ma.us/ballot_questions/view/1367/

Minnis, D. L. (1998). Wildlife policy-making by the electorate: An overview of citizen-sponsored ballot measures on hunting and trapping. Wildlife Society Bulletin, 26(1), 75-83.

MSPCA. (2015). 2015-2016 Massachusetts Legislative Session. Retrieved from https://www.mspca. org/animal_protection/2015-2016-session-archive/ on November 3, 2017.

Ordiz, A., Bischof, R., \& Swenson, J. E. (2013). Saving large carnivores, but losing the apex predator?. Biological Conservation, 168, 128-133. doi:10.1016/j.biocon.2013.09.024

Ordiz, A., Støen, O. G., Sæbø, S., Sahlen, V., Pedersen, B. E., Kindberg, J., \& Swenson, J. E. (2013). Lasting behavioural responses of brown bears to experimental encounters with humans. Journal of Applied Ecology, 50(2), 306-314. doi:10.1111/1365-2664.12047

Peterson, M. N., \& Nelson, M. P. (2017). Why the North American Model of Wildlife Conservation is problematic for modern wildlife management. Human Dimensions of Wildlife, 22(1), 43-54. doi:10.1080/10871209.2016.1234009

Ramp, D., \& Bekoff, M. (2015). Compassion as a Practical and Evolved Ethic for Conservation. BioScience, 65, 323-327. doi:10.1093/biosci/biu223

Ripple, W. J., Estes, J. A., Beschta, R. L., Wilmers, C. C., Ritchie, E. G., Hebblewhite, M., ... Wirsing, A. J. (2014). Status and ecological effects of the world's largest carnivores. Science, 343, 151-162. doi:10.1126/science.1241484

Robinson, H. S., Wielgus, R. B., Cooley, H. S., \& Cooley, S. W. (2008). Sink populations in large carnivore management: Cougar demography in a hunted population. Ecological Applications, 18 (4), 1028-1037. doi:10.1890/07-0352.1

Slagle, K., Bruskotter, J. T., Singh, A. S., \& Schmidt, R. H. (2017). Attitudes toward predator control in the United States: 1995 and 2014. Journal of Mammalogy, 98, 7-16.

Teel, T., \& Manfredo, M. (2010). Understanding the diversity of public interests in wildlife conservation. Conservation Biology, 24, 128-139. doi:10.1111/cbi.2010.24.issue-1

Treves, A., \& Bruskotter, J. T. (2014). Tolerance for predatory wildlife. Science, 344, 476-477. doi:10.1126/science. 1252690

Treves, A., Chapron, G., Lopez-Bao, J. V., Shoemaker, C., Goeckner, A. R., \& Bruskotter, J. T. (2015). Predators and the Public Trust. Biological Reviews, 92, 248-270. doi:10.1111/brv.12227 
Treves, A., Krofel, M., \& McManus, J. (2016). Predator control should not be a shot in the dark. Frontiers of Ecology and Environment, 14(7), 380-388. doi:10.1002/fee.1312

Treves, A., Naughton-Treves, L., \& Shelley, V. (2013). Longitudinal analysis of attitudes toward wolves. Conservation Biology, 27, 315-323. doi:10.1111/cobi.12009

USFWS. (2011). 2011 National Survey of Fishing, Hunting and Wildlife-Associated Recreation. Retrieved from http://digitalmedia.fws.gov/cdm/ref/collection/document/id/1684

Vaske, J. J. (2008). Survey research and analysis: Applications in parks, recreation and human dimensions. State College, PA: Venture Publishing

Vucetich, J., \& Nelson, M. P. (2014). Wolf hunting and the ethics of predator control. In Linda Kalof (Ed.), Political science, comparative politics, political theory. Oxford, UK: Oxford Handbooks Online.

Wallach, A. D., Bekoff, M., Nelson, M. P., \& Ramp, D. (2015). Promoting predators and compassionate conservation. Conservation Biology, 29, 1481-1484. doi:10.1111/cobi.12525

Way, J. G. (2007). Suburban Howls: Tracking the Eastern Coyote in urban Massachusetts. Indianapolis, IN: Dog Ear Publishing.

Way, J. G., Timm, B. C., \& Strauss, E. G. (2009). Coywolf (Canis latrans x lycaon) Pack Density Doubles Following the Death of a Resident Territorial Male. Canadian Field Naturalist, 123(3), 199-205. doi:10.22621/cfn.v123i3.964 